\title{
PENERAPAN MODEL KOOPERATIF TIPE SIMULTANEOUS ROUNDTABLE UNTUK MENINGKATKAN \\ KETERAMPILAN SOSIAL SISWA
}

\author{
Agus Sriwulan
}

SDN Tunjungsekar 5 Kota Malang

Email: agussriwulan1563@gmail.com

\begin{abstract}
ABSTRAK
Penelitian ini bertujuan mendeskripsikan penerapan model kooperatif tipe Simultaneous RoundTable untuk meningkatkan keterampilan sosial siswa di SDN Tunjungsekar 5 Malang. Jenis penelitian ini merupakan Penelitian Tindakan Kelas yang terdiri dari 2 siklus. Masing-masing siklus terdiri dari empat tahap, yaitu tahap perencanaan, pelaksanaan, pengamatan, dan refleksi. Subjek penelitian ini adalah siswa kelas II B SDN Tunjungsekar 5 Malang tahun pelajaran 2015/2016 yang berjumlah 25 orang. Data tentang keterampilan sosial siswa dikumpulkan melalui lembar observasi dan wawancara. Data yang telah terkumpul kemudian dianalisis dengan menggunakan teknik analisis deskriptif kualitatif. Pada siklus I, persentase keterampilan sosial siswa diperoleh hasil sebesar 55\% dan mengalami peningkatan yang signifikan pada siklus II sebesar $87 \%$. Berdasarkan hasil penelitian ini, menunjukkan adanya peningkatan keterampilan sosial siswa melalui penerapan model kooperatif tipe Simultaneous RoundTable yang mencakup sub aspek (1) kemampuan berkomunikasi dengan siswa lain, (2) menjalin hubungan pertemanan dengan teman sebaya, (3) mendengarkan pendapat teman, (4) memberi dan menerima kritik dari orang lain, dan (5) memberi atau menerima umpan balik.
\end{abstract}

Kata Kunci: Model kooperatif tipe Simultaneous RoundTable, Keterampilan sosial siswa

\begin{abstract}
This study aims to describe the implementation of Simultaneous RoundTable model of cooperative model to improve students' social skills in Tunjungsekar 5 Elementary School Malang. This type of research is a Classroom Action Research consist of 2 cycles. Each cycle consists of four stages, planning, implementation, observation, and reflection. The subjects of this research are 25 students in II B class of Tunjungsekar 5 Elementary School Malang year 2015/2016. Data on students' social skills are collected through observation sheets and interviews. The collected data then analyzed by using qualitative descriptive analysis technique. In the first cycle, the percentage of social skills of students by $55 \%$ and experienced a significant increase in cycle II of
\end{abstract}


$87 \%$. Based on the results of this study, students 'social skills are enhanced through the application of Simultaneous RoundTable model of cooperation which includes sub aspect (1) the ability to communicate with other students, (2) make friendship with peers, (3) listen to friends' opinions, (4) giving and receiving criticism from others, and (5) giving or receiving feedback.

\section{Keywords: Simultaneous RoundTable type of Cooperative model, Students' social skills}

\section{PENDAHULUAN}

Kurikulum 2013 tersusun dari landasan fisiologis yang bermaksud untuk mengembangkan potensi peserta didik menjadi kemampuan dalam berpikir reflektif bagi penyelesaian masalah sosial di masyarakat, dan untuk membangun kehidupan masyarakat demokratis yang lebih baik. Kurikulum 2013 menerapkan sistem pembelajaran tematik yang dipadu dengan pendekatan lima pengalaman belajar siswa. Lima pengalaman belajar siswa yang dimaksud antara lain, mengamati, mengajukan pertanyaan, mengumpulkan data/mencoba, menganalisis, dan mengkomunikasikan sehingga kurikulum 2013 lebih menekankan pengembangan kompetensi pengetahuan, keterampilan, dan sikap siswa secara holistik ${ }^{13}$. Dengan pendekatan tersebut, diharapkan peserta didik memperoleh pemahaman yang lebih luas dan mendalam pada bidang ilmu pengetahuan yang diajarkan pada jenjang sekolah dasar.

Mengacu pada landasan tersebut, maka dapat dipahami bahwa pembelajaran seyogianya berorientasi pada pengembangan keterampilan, pengetahuan, dan sikap melalui pembelajaran yang interaktif edukatif. Adanya interaksi siswa dalam kelompok menyingkirkan persaingan

13 Herry Widyastono, Pengembangan Kurikulum di Era Otonomi Daerah; dari kurikulum 2004, 2006, ke kurikulum 2013, (Jakarta: Bumi Aksara, 2014), hlm. 19. yang terdapat di dalam kelas, mendorong siswa untuk bekerjasama saling membantu sama lain, dan mendidik sikap-sikap antarkelompok yang positif di dalam ruang kelas yang beragam ${ }^{14}$. Interaksi sehat yang terjalin antara guru dengan siswa dan siswa dengan siswa lainnya memberikan kesempatan luas bagi siswa untuk mendukung kesuksesan hubungan sosial dan memungkinkan individu bekerjasama mengembangkan diri secara efektif.

Berdasarkan hasil observasi yang dilakukan di SDN Tunjungsekar 5 Malang pada siswa kelas II, menunjukkan bahwa keterampilan sosial yang dimiliki siswa masih rendah dengan hasil $45 \%$ dari total keseluruhan siswa sebanyak 25 orang. Hal ini dilatarbelakangi oleh kurangnya strategi pembelajaran yang menekankan pada aktivitas diskusi sehingga siswa hanya melakukan interkasi dan kerjasama hanya dengan teman yang dianggap dekat atau teman yang memiliki tingkat akademis yang baik. Selain itu, maraknya perkelahian dan adu mulut yang terjadi antarsiswa yang disebabkan oleh ejekan memanggil nama orangtua. Rentannya perselisihan ini dimaknai kurangnya rasa menghargai perbedaan dan kepedulian antarsiswa.

Keterampilan sosial merupakan suatu

14 James Banks, An Introduction to Multicultural Education (4th ed.), (Boston: Allyn \& Bacon, 2006). 
keterampilan yang berfungsi sebagai jembatan untuk memperoleh hubungan yang baik (feedback) dalam berinteraksi dengan orang lain. Pentingnya berbagai macam keterampilan sosial bagi siswa saat ini sangat diperlukan untuk diterapkan dalam proses pembelajaran (1) karena adanya kecenderungan negatif dalam hubungan sosial, generasi muda cenderung individualistis, (2) melemahnya rasa sosial dan rasa empati kepada orang lain, (3) sering terjadi konflik sosial di masyarakat, dan (4) adanya kecenderungan saling ketergantungan dalam kehidupan sosial sejalan dengan arus globalisasi ${ }^{15}$.

Keterampilan sosial dapat dicapai melalui penerapan model pembelajaran yang menekankan pada diskusi kelompok salah satunya yaitu model kooperatif tipe Simultaneous RoundTable ${ }^{16}$. Dalam kelompok, siswa secara mandiri dan memiliki kesempatan untuk bekerjasama, belajar bersama, berkomunikasi, peduli, dan menghargai. Diskusi kelompok merupakan strategi pengajaran yang ditandai dengan menurunnya fokus pada guru, meningkatnya interaksi antarsiswa, dan berkembangnya keterlibatan siswa dalam ruang kelas. Interaksi sosial yang terjalin memungkinkan siswa melakukan sharing, membantu siswa melihat dan memberdayakan gagasan-gagasan dengan cara yang berbeda ${ }^{17}$.

15 Benyamin Maftuh, Memperkuat Peran IPS dalam Membelajarkan Keterampilan Sosial dan Resolusi Konflik, Makalah Disajikan dalam Pidato Pengukuhan Guru Besar dalam Bidang Pendidikan IPS pada FPIPS UPI. (Bandung: Universitas Pendidikan Indonesia, 2010).

16 Spencer Kagan and Miguel Kagan, Cooperative Learning, (San Clemente: Kagan Publishing, 2009), hlm. 20.

17 Paul Eggen \& Donald Kauchak, Educational Psychology: Windows on Classroom (7th ed.), (Upper Sadle River: Pearson, 2007), hlm. 97.
Diskusi kelompok mendorong siswa untuk menyumbangkan pemikiran atau ide mereka, mendorong siswa untuk saling membantu satu sama lain, yang pada akhirnya memberikan ukuran keberhasilan mereka masing-masing.

Berdasarkan latar belakang yang telah diuraikan di atas, maka rumusan masalah penelitian ini adalah bagaimanakah penerapan model kooperatif tipe Simultaneous RoundTable dapat meningkatkan keterampilan sosial siswa kelas II B SDN Tunjungsekar 5 Malang.

Hasil penelitian ini diharapkan akan memberi manfaat: (1) Bagi guru, diharapkan hasil penelitian ini dapat dijadikan sumber informasi dalam menentukan model pembelajaran yang efektif sehingga dapat meningkatkan keterampilan sosial siswa; (2) Bagi siswa, diharapkan hasil penelitian ini dapat memberikan pengalaman belajar dan motivasi siswa dalam kegiatan pembelajaran untuk meningkatkan keterampilan sosial; (3) Bagi peneliti lain, hasil penelitian ini sebagai referensi penelitian lanjutan yang relevan.

\section{METODE PENELITIAN}

Penelitian ini menggunakan pendekatan deskriptifkualitatif. Menurutjenisnya penelitian ini menggunakan rancangan Penelitian Tindakan Kelas (Classroom Action Research) yang dilaksanakan pada semester 2 tahun pelajaran 2015/2016 di SDN Tunjungsekar 5 Malang. Penelitian ini dipilih karena dilakukan untuk memecahkan masalah pembelajaran di kelas dengan terperinci dimulai dari observasi awal sampai pemilihan model pembelajaran yang sesuai dengan permasalahan yang muncul saat kegiatan pembelajaran. Penelitian tindakan kelas adalah penyelidikan melalui pengumpulan data oleh guru dengan maksud 
membuat penilaian tentang cara dan teknik untuk meningkatkan praktik pengajaran guru itu sendiri ${ }^{18}$.

Subjek penelitian ini adalah siswa kelas II B SDN Tunjungsekar 5 Malang sebanyak 25 orang yang terdiri dari 14 siswa laki-laki dan 9 siswa perempuan. Alasan pemilihan kelas II B SDN Tunjungsekar 5 didasarkan dengan pertimbangan bahwa keterampilan bertanya siswa yang lebih rendah dibandingkan kelas II A. Selanjutnya, penelitian ini dilaksanakan dalam 2 siklus, setiap siklus memuat tahapan perencanaan, pelaksanaan dan pengamatan, refleksi ${ }^{19}$. Desain penelitian ini dapat digambarkan dengan model sebagai berikut.

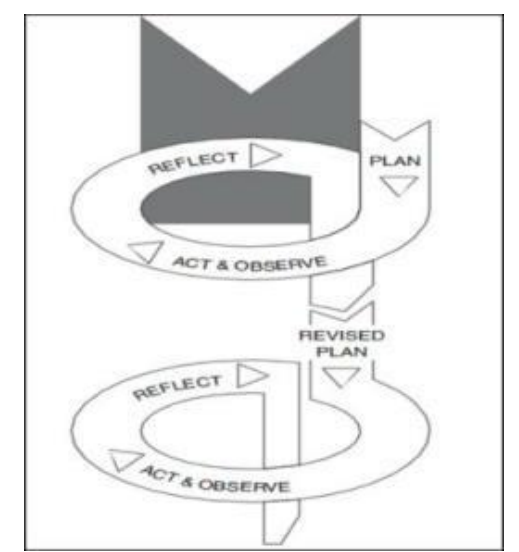

Gambar 1. Desain Penelitian Tindakan Kelas Model Spiral Kemmis \& Taggart

Pada tahap perencanaan ini yang dilakukan oleh peneliti meliputi; (a) menyusun perangkat pembelajaran yaitu Rencana Pelaksanaan Pembelajaran (RPP). RPP yang dibuat mencakup tema Tema 7 Merawat Hewan dan Tumbuhan Sub Tema 1 Hewan di Sekitarku; (b) menyusun dan menyiapkan model

18 Stephen Kemmis, Robin Mc. Taggart, and Rhonda Nixon, The Action Research Planner, (New York: Springer, 2014), hlm 11.

19 Stephen Kemmis, Robin Mc. Taggart, and Rhonda Nixon, The Action Research Planner, (New York: Springer, 2014), hlm 19. pembelajaran Simultaneous RoundTable; (d) membuat instrumen penelitian yaitu lembar observasi dan pedoman wawancara.

Pelaksanaan tindakan ini disesuaikan dengan perencanaan pelaksanaan pembelajaran (RPP) yang telah disusun berdasarkan pembelajaran model Simultaneous RoundTable. Diawali dengan tahap pendahuluan oleh guru, melakukan apersepsi, menjelaskan tujuan pembelajaran, selanjutnya menerapkan model Simultaneous RoundTable dengan tahapan sebagai berikut, (1) guru menentukan topik diskusi, (2) siswa mulai menyelesaikan tugas melalui tulisan atau gambar, (3) waktu peneyelesaian masing-masing siswa ditentukan oleh guru, (4) siswa saling bertukar pekerjaan untuk melanjutkan pekerjaan tersebut searah jarum jam, (5) siswa mempresentasikan hasil pekerjaannya.

Kegiatan observasi dalam penelitian ini dilakukan terhadap pelaksanaan tindakan yang dilakukan selama pelaksanaan pembelajaran. Hal-hal yang perlu diamati oleh observer adalah keterampilan sosial siswa dalam kelompok yang meliputi sub aspek (1) kemampuan berkomunikasi dengan siswa lain, (2) menjalin hubungan pertemanan dengan teman sebaya, (3) mendengarkan pendapat teman, (4) memberi dan menerima kritik dari orang lain, dan (5) memberi atau menerima umpan balik.

Kegiatan refleksi dilakukan oleh guru dan peneliti di setiap akhir siklus untuk mengetahui keberhasilan tindakan melalui kriteria yang ditentukan, yaitu $\geq 75 \%$ yang diperoleh dari data observasi kepada 25 siswa dan wawancara kepada 6 subjek terpilih berdasarkan tingkat akademis siswa.

Data yang diproleh dari hasil observasi dan wawancara dianalisis dengan menggunakan teknik analisis data deskriptif kualitatif 
untuk memastikan bahwa penerapan model Simultaneous RoundTable dapat meningkatkan keterampilan sosial siswa kelas II B SDN Tunjungsekar 5 Malang. Selanjutnya, data dievaluasi untuk mengetahui keberhasilan tindakan atau sebagai acuan tindak lanjut siklus. Adapun kriteria evaluasi keberhasilan persiklus penerapan model pembelajaran Simultaneous RoundTable untuk meningkatkan keterampilan sosial siswa diuraikan pada tabel berikut (hlm. 16).

\section{HASIL DAN PEMBAHASAN Hasil Siklus I}

Berdasarkan observasi dan wawancara yang dilakukan kepada seluruh siswa kelas II B yang berjumlah 25 orang dan wawancara kepada 6 subjek terpilih pada akhir pertemuan siklus I dapat diperoleh hasil pada tabel berikut (hlm. 16).

Berdasarkan tabel2 dapat diketahui bahwa pada aspek keterampilan sosial siswa mengalami peningkatan dari hasil observasi pratindakan, yaitu $45 \%$ setelah dilakukan tindakan menjadi 55\%. Rata-rata ketercapaian sub aspek kemampuan berkomunikasi diperoleh hasil bahwa sebagian besar siswa memiliki keberanian dan keinginan untuk mengajukan pertanyaan walaupun belum menggunakan kosa kata baku. Peningkatan yang sama juga terjadi pada sub aspek kemampuan menjalin hubungan pertemanan dengan teman yang ditandai dengan adanya usaha untuk berpartisipasi dalam diskusi dengan mencari bahan atau materi pemecahan masalah melalui buku yang dimiliki siswa. Perbedaan hasil juga muncul pada sub aspek kemampuan mendengarkan pendapat teman yang ditunjukkan dengan memperhatikan saat teman berbicara meskipun guru harus mengkondisikan suasana kelas terlebih dahulu.
Berbeda halnya pada sub aspek kemampuan memberi dan menerima kritik dari teman yang hanya mengalami peningkatan sebesar $4 \%$. Hal ini disebabkan oleh ketidaktahuan siswa tentang cara dalam mengkritisi sebuah jawaban atau ide. Akan tetapi siswa mampu menghargai pendapat teman dengan memberikan apresiasi atau pujian dengan bentuk tepuk tangan sehingga pada sub aspek kemampuan memberi dan menerima umpan balik mengalami peningkatan yang cukup positif.

Data hasil analisis siklus $\mathrm{I}$ di atas menunjukkan bahwa keseluruhan aspek yang diteliti belum mencapai kriteria keberhasilan tindakan. Keterlaksanaan model pembelajaran Simultaneous RoundTable diperoleh 55\% atau di bawah kriteria keberhasilan sebesar $\geq 75 \%$. Artinya, keterampilan sosial siswa pada kelima sub aspek yang ditentukan dinyatakan belum berhasil.

\section{Hasil Siklus II}

Berdasarkan observasi dan wawancara yang dilakukan kepada seluruh siswa kelas II B yang berjumlah 25 orang dan wawancara kepada 6 subjek terpilih pada akhir pertemuan siklus II dapat diperoleh hasil pada tabel berikut. 
Tabel 1. Kriteria Keberhasilan Siswa

\begin{tabular}{|c|l|l|c|}
\hline No & Aspek & \multicolumn{1}{|c|}{ Sub Aspek } & $\begin{array}{c}\text { Target Pencapaian Rata-ra- } \\
\text { ta Kelas dalam Persentase }\end{array}$ \\
\hline 1 & $\begin{array}{l}\text { Keterampilan } \\
\text { sosial }\end{array}$ & $\begin{array}{l}\text { Kemampuan berkomunikasi dengan } \\
\text { teman sebaya }\end{array}$ & \multirow{2}{*}{$\begin{array}{l}\text { Menjalin hubungan pertemanan dengan } \\
\text { teman sebaya }\end{array}$} \\
& & Mendengarkan pendapat teman & \\
& $\begin{array}{l}\text { Memberi dan menerima kritik dari orang } \\
\text { lain }\end{array}$ & \\
\cline { 3 - 3 } & Memberi atau menerima umpan balik & \\
\hline
\end{tabular}

(Olahan peneliti, 2016)

Tabel 2. Hasil observasi dan wawancara Keterampilan sosial Siswa Siklus I

\begin{tabular}{|c|c|c|c|c|c|}
\hline \multirow{2}{*}{ No } & \multirow{2}{*}{ Aspek } & \multirow{2}{*}{ Sub Aspek } & \multirow{2}{*}{$\begin{array}{c}\text { Sebelum } \\
\text { Tindakan }\end{array}$} & \multicolumn{2}{|c|}{ Setelah Tindakan } \\
\hline & & & & $\mathbf{O}$ & $\mathbf{W}$ \\
\hline \multirow[t]{5}{*}{1.} & $\begin{array}{l}\text { Keterampilan } \\
\text { Sosial }\end{array}$ & $\begin{array}{l}\text { Kemampuan berkomuni- } \\
\text { kasi dengan teman sebaya }\end{array}$ & $64 \%$ & $72 \%$ & $33 \%$ \\
\hline & & $\begin{array}{l}\text { Menjalin hubungan per- } \\
\text { temanan dengan teman } \\
\text { sebaya }\end{array}$ & $64 \%$ & $76 \%$ & $59 \%$ \\
\hline & & \begin{tabular}{|l|} 
Mendengarkan pendapat \\
teman
\end{tabular} & $32 \%$ & $64 \%$ & $50 \%$ \\
\hline & & $\begin{array}{l}\text { Memberi dan menerima } \\
\text { kritik dari orang lain } \\
\end{array}$ & $36 \%$ & $40 \%$ & $67 \%$ \\
\hline & & $\begin{array}{l}\text { Memberi atau menerima } \\
\text { umpan balik }\end{array}$ & $28 \%$ & $54 \%$ & $33 \%$ \\
\hline \multicolumn{3}{|c|}{ Rata-rata } & $45 \%$ & $61 \%$ & $48 \%$ \\
\hline \multicolumn{3}{|c|}{ Rata-rata Keterampilan Sosial siswa Siklus I } & & $55 \%$ & \\
\hline
\end{tabular}

(Sumber: Hasil Observasi dan Wawancara Keterampilan sosial Siswa Siklus I olahan peneliti, 2016)

Tabel 3. Hasil observasi dan Wawancara Keterampilan sosial Siswa Siklus II

\begin{tabular}{|c|l|l|c|c|}
\hline No & \multicolumn{1}{|c|}{ Aspek } & \multicolumn{1}{|c|}{ Sub Aspek } & O & W \\
\hline 1. & $\begin{array}{l}\text { Keterampilan } \\
\text { sosial }\end{array}$ & $\begin{array}{l}\text { Kemampuan berkomunikasi den- } \\
\text { gan teman sebaya }\end{array}$ & $96 \%$ & $100 \%$ \\
\hline & & $\begin{array}{l}\text { Menjalin hubungan pertemanan } \\
\text { dengan teman sebaya }\end{array}$ & $80 \%$ & $84 \%$ \\
\hline & Mendengarkan pendapat teman & $90 \%$ & $56 \%$ \\
\hline & $\begin{array}{l}\text { Memberi dan menerima kritik dari } \\
\text { orang lain }\end{array}$ & $90 \%$ & $84 \%$ \\
\hline & $\begin{array}{l}\text { Memberi atau menerima umpan } \\
\text { balik }\end{array}$ & $96 \%$ & $92 \%$ \\
\hline \multicolumn{2}{|l|}{ Rata-rata } & $90 \%$ & $83 \%$ \\
\hline \multicolumn{2}{|l|}{ Rata-rata Keterampilan sosial siswa siklus II } \\
\hline
\end{tabular}

(Sumber: Hasil Observasi dan Wawancara Keterampilan sosial Siswa Siklus II olahan peneliti, 2016) 
Berdasarkan tabel3. tentang hasil observasi dan wawancara tentang keterampilan sosial siswa terhadap penerapan model Simultaneous RoundTable mengalami peningkatan signifikan dari $55 \%$ pada siklus I menjadi $87 \%$ pada siklus II. Rata-rata ketercapaian sub aspek kemampuan berkomunikasi diperoleh hasil bahwa sebagian besar siswa memiliki keberanian dan keinginan untuk mengajukan pertanyaan disertai penggunaan bahasa Indonesia yang baik dan benar. Peningkatan yang sama juga terjadi pada sub aspek kemampuan menjalin hubungan pertemanan dengan teman yang ditandai dengan adanya partisipasi aktif dalam diskusi dengan mencari bahan atau materi pemecahan masalah melalui buku yang dimiliki siswa. Perbedaan hasil juga muncul pada sub aspek kemampuan mendengarkan pendapat teman yang ditunjukkan dengan memperhatikan saat teman berbicara dengan latar belakang siswa ingin membandingkan jawaban dan mengetahui pendapat teman. Adapun peningkatan yang sangat positif pada sub aspek kemampuan memberi dan menerima kritik dari teman yang ditandai dengan perhatian terhadap setiap ungkapan kritikan yang disampaikan teman. Selanjutnya, secara klasikal memberikan apresiasi terhadap kritik, jawaban, dan pendapat teman melalui tepuk tangan, sorakan, bahkan siulan.

Berdasarkan observasi selama pelaksanaan tindakan pada siklus I dan siklus II ditemukan hasil penelitian menunjukkan peningkatan pada beberapa aspek yang ditetapkan dalam penelitian ini. Analisis peningkatan pada kedua aspek tersebut digambarkan dalam grafik batang berikut ini.

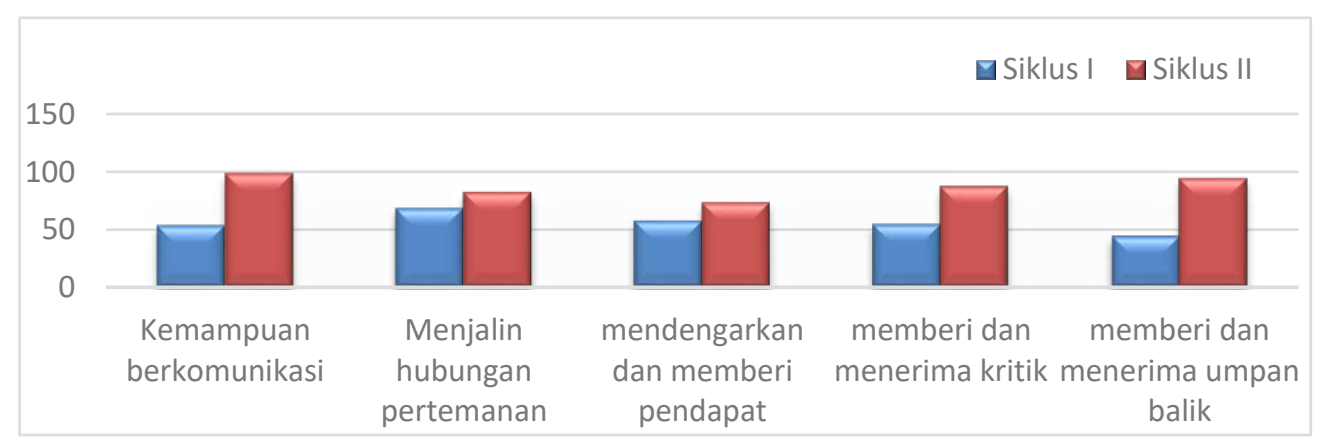

Gambar 2. Grafik Peningkatan Temuan Hasil Penelitian Tindakan pada Siklus I dan Siklus II 
Konklusi dari hasil analisis yang telah ditunjukkan dari grafik di atas menunjukkan bahwa pembelajaran pada siklus II sudah berhasil karena aspek dalam kriteria keberhasilan persiklus yakni keterampilan sosial siswa sudah mencapai kriteria yang ditetapkan dalam penelitian ini.

Terpenuhinya aspek keterampilan sosial siswa diakomodir oleh penerapan model Simultaneous RoundTable. Sintaks model Simultaneous RoundTable secara berturutturut memberikan stimulasi bagi siswa untuk memberikan kontribusi ide berupa tulisan, gambar atau hal lain. Diskusi dalam kelompok secara positif dapat meningkatkan kualitas interaksi antar siswa sehingga memunculkan kedekatan secara sosio emosional kepada masing-masing siswa. Interaksi sosial memungkinkan bagi siswa untuk melakukan sharing atas perspektif alternatif sehingga siswa dapat mengkonstruksi pengetahuan dan membudayakan gagasan orang lain ${ }^{20}$.

Hasil observasi dan wawancara menunjukkan bahwa siswa secara mandiri dan spontan mengajukan pertanyaan kepada temannya disertai penggunaan bahasa Indonesia yang baik dan benar. Kemajuan kosa kata dan tata bahasa pada siswa sekolah dasar merupakan bekal siswa dalam mengembangkan kemampuan metalinguistik termasuk kapasitas untuk membaca, memahami dan kritis menghargai berbagai bentuk komunikasi termasuk bahasa lisan, teks tercetak, media

20 Paul Eggen \& Donald Kauchak, Educational Psychology: Windows on Classroom (7th ed.), (Upper Sadle River: Pearson, 2007), hlm. 101 penyiaran, dan media ${ }^{21}$. Oleh karenanya budaya berbahasa yang baik, menjadi bekal sekaligus menimbulkan motivasi dan harapan kepada siswa untuk unjuk diri di dalam kelas.

Berdasarkan hasil observasi dan wawancara menunjukkan kegiatan diskusi kelompok yang membudaya; mandiri, sehat, dan aktif. Hal ini tampak dari perilaku masingmasing siswa untuk berinteraksi, berbagi ide, suka rela menerima perbedaan gender, suku, dan akademis. Diperkuat oleh alasan siswa bahwa kegiatan diskusi dapat berjalan karena adanya ajakan dan pembagian tugas seara terstruktur oleh ketua kelompok masingmasing. Siswa yang bekerjasama melalui kelompok meningkatkan skill-skill sosial, mengembangkan sikap menerima atas keunikan teman, dan menciptakan persahabatan ${ }^{22}$.

Berdasarkan hasil wawancara dan observasi diperoleh kesimpulan bahwa siswa secara sadar memiliki keterampilan dalam menerima dan merespon terhadap pendapat. Hal ini dilatarbelakangi oleh alasan siswa bahwa mereka mendapatkan motivasi dari temannya untuk memberikan kesempatan yang sama bagi semua anggota mengemukakan ide yang dimiliki tanpa rasa malu dan takut salah. Di sisi lain, siswa memperhatikan dengan seksama pendapat-pendapat yang disampaikan teman dengan alasan adanya keinginan untuk menghargai, mengetahui, dan membandingkan

21 Departement of education and Skills, Literacy and numeracy for learning and life: The national strategy to improve literacy and numeracy among children and young people 2011-2020, (Dublin: Goverment Publications, 2011), hlm. 43.

22 Sharon R. Vaughn, Candace S. Bos, \& Jeane Shay Schumm, Teaching Exceptional, diverse, and at-Risk Student in the General Education Classromm (3th ed.), (Boston: Allyn \& Bacon, 2006), hlm. 75. 
pandangan yang dimiliki sehingga dapat menjadi jalan untuk memperoleh informasi baru yang lebih detail. Perilaku ini menyiratkan bahwa siswa memiliki sikap, nilai, dan kepercayaan yang berharga seperti yang memberi dan menerima muncul dari dalam diri siswa sendiri untuk berkomitmen, berkemauan untuk mendiskusikan dan mendukung suatu posisi tertentu sesuai dengan nilai yang dimiliki ${ }^{23}$.

Berdasarkan hasil observasi dan wawancara menunjukkan bahwa siswa secara spontan dan mandiri mengkritisi ide atau jawaban teman dengan alasan bahwa adanya perbedaan pendapat, jawaban teman kurang tepat, dan lengkap. Timbulnya alasan ini diindikasikan sebagai kepekaan siswa untuk melakukan penilaian atau evaluasi terhadap informasi yang didengar dan dilihat melalui serangkaian bukti yang didapatkan. Pencapaian siswa pada tingkatan ini juga diasumsikan sebagai kemampuan berpikir tingkat tinggi yang melibatkan siswa untuk berpikir produktif dan alasan yang rasional ${ }^{24}$. Selanjutnya, kerelaan siswa menerima kritikan ditandai dengan ekspresi siap, tersenyum, dan tetap ramah. Hal ini dapat dimaknai sebagai usaha siswa untuk mengkroscek ulang pemikiran yang diyakini sebagai bentuk keterbukaan pikiran terhadap gagasan baru ${ }^{25}$.

Berdasarkan hasil observasi dan wawancara

23 David A. Jacobsen, Paul Eggen, \& Donald Kauchak, terjemhan, Metode-metode pengajaran,, (Yogyakarta: Pustaka Pelajar, 2009), hlm. 231.

24 Alan Bensley, Deborah S. Crowe, \& Paul Bernhardt, Teaching and Assessing Critical Thinking Skills For Argument Analysis In Psychology. Teaching of Psychology, No. 37 (2010): 95.

25 David A. Jacobsen, Paul Eggen, \& Donald Kauchak, terjemhan, Metode-metode pengajaran, (Yogyakarta: Pustaka Pelajar, 2009), hlm. 236. menunjukkan bahwa adanya budaya memberikan apresiasi terhadap jawaban teman dengan variasi siulan, tepuk tangan, dan sorakan. Apresiasi ini didapatkan siswa melalui penyelesaian tugas dengan cepat, benar, dan berani. Munculnya pencapaian ini didasari oleh keinginan kuat mendapatkan pujian dan pengakuan, maka timbulnya kondisi siswa secara sehat bersaing dan berlomba untuk mendapatkan kebanggan baik secara individu maupun kelompok. Timbulnya pujian diyakini menjadi suatu dorongan kuat bagi siswa untuk memperoleh pengakuan, posisi, dan penilaian kemampuan diri. Oleh karena itu, secara interaksi edukatif dalam kelas sangat perlu diciptakan melalui motivasi ekstrinsik, yaitu berupa pujian dan hadiah ${ }^{26}$.

\section{KESIMPULAN}

Keterampilan sosial yang dimiliki siswa meliputi lima sub aspek antara lain: (1) kemampuan berkomunikasi dengan siswa lain, (2)menjalinhubunganpertemanandenganteman sebaya, (3) mendengarkan pendapat teman, (4) memberi dan menerima kritik dari orang lain, dan (5) memberi atau menerima umpan balik. Kelima sub aspek tersebut dijembatani oleh alur model Simultaneous RoundTable yang terbukti secara efektif dapatmeningkatkan interaksi, kerjasama, berbagi, dan menghargai dalam lingkup intrakelompok dan antarkelompok.

26 Syaiful Bahri Djamarah, Guru dan Anak Didik dalam Interaksi Edukatif, (Jakarta: Rineka Cipta, 2010), hlm. 117. 


\section{DAFTAR PUSTAKA}

Djamarah, S. Guru dan Anak Didik Dalam Interaksi Edukatif: Suatu Pendekatan Teoritis Psikologis. Jakarta: Rineka Cipta, 2010.

Department of Education and Skills (DES). Literacy and numeracy for learning and life: The national strategy to improve literacy and numeracy among children and young people 2011-2020. Dublin: Government Publications, 2011.

Banks, J. An Introduction to Multicultural Education (4th ed.). Boston: Allyn \& Bacon, 2006.

Bensley, D. Teaching and Assessing Critical Thinking Skills For Argument Analysis In Psychology. Teaching of Psychology, 37, 2010.

Eggen, P., \& Kauchak, D. Educational Psychology: Windows on Classroom (7th ed.). Upper Sadle River, NJ: Pearson, 2007.

Jacobsen, D., Eggen, P., Kauchak, D. Methods For Teaching. New Jersey: Pearson Education, Inc., 2009.

Kagan, S., \& Kagan, M. Kagan Cooperative Learning. San Clemente: Kagan Publishing, 2009.

Kemmis, S., McTaggart, R., Nixon, R. The Action Research Planner. New York: Springer, 2014.

Maftuh, B. Memperkuat Peran IPS dalam Membelajarkan Keterampilan Sosial dan Resolusi Konflik. Makalah Disajikan dalam Pidato Pengukuhan Guru Besar dalam Bidang Pendidikan IPS pada FPIPS UPI. Bandung: Universitas Pendidikan Indonesia, 2010.
Vaughn, S., Bos, C., Candace, S., \& Schumm, J. Teaching Exceptional, diverse, and at-Risk Student in the General Education Classromm (3th ed.). Boston: Allyn \& Bacon, 2006.

Widyastono, H. Pengembangan Kurikulum Di Era Otonomi Daerah (Dari Kurikulum 2004, 2006 ke Kurikulum 2013). Jakarta: Bumi Aksara, 2014. 